\title{
Effect of diets fortified with Nigella sativa, sesame seeds and high calcium on osteoporosis in ovariectomized rats
}

\author{
Reham S. Ramadan \\ Nutrition and Food Sciences Department, Faculty of Home Economics, \\ Helwan University
}

\begin{abstract}
The study was carried out to assess the effect of diets fortified with Nigella sativa (NS), sesame (SS) seeds and high calcium $(\mathrm{Ca})$ on osteoporosis in ovariectomized $(\mathrm{OVX})$ rats. Fifty six rats were randomized into 8 equal groups $(n=$ 7) and housed individually in metal metabolic cages. Under ether anesthesia, group (1) was SHAM-operated and fed on basal diet, while the other 7 groups were bilaterally OVX-operated. Three weeks after ovariectomy, group (2) was fed on basal diet, while groups (3), (4), (5), (6) and (7) were fed on experimental diets fortified with the following: $10 \%$ NS; $10 \%$ SS; $2 \% \mathrm{Ca} ; 10 \% \mathrm{NS}+2 \% \mathrm{Ca}$ and $10 \% \mathrm{SS}+2 \% \mathrm{Ca}$, respectively for 6 weeks. Group (8) was fed on basal diet and given orally Alendronate (anti-osteoporotic drug) in a daily dose of $3 \mathrm{mg} / \mathrm{kg}$ for 6 weeks. During feeding period, initial and final body weights of rats were recorded. At the end of the experiment, the last $24 \mathrm{hr}$ urine samples were collected for estimating $\mathrm{Ca}, \mathrm{P}$, pyridinoline (PD) and deoxypyridinoline (DPD) concentrations. Rats were then euthanized by prolonged exposure to anesthetic ether. Blood samples were collected for estimating serum calcium (Ca), phosphorous $(\mathrm{P})$, bone-specific alkaline phosphatase (b-ALP) and osteocalcin (OC) levels. The uteri were dissected out and weighed. Femur bones also were dissected out and used for measurement and analysis of bone ash. The results showed that diets fortified with NS and SS and high calcium prevented the increase in body weight gain and the decrease in uterine weight induced by ovariectomy. These experimental diets normalized serum $\mathrm{Ca}, \mathrm{P}, \mathrm{b}-\mathrm{ALP}$ and OC levels and decreased urinary excretion of $\mathrm{Ca}, \mathrm{P}, \mathrm{PD}$ and DPD. There were also significant increases in femur bone mineral density (BMD) and calcium content in bone ash. In conclusion, diets fortified with NS, SS and high calcium have a promising antiosteoporotic effect in OVX rats. The study recommends enrichment of the bakeries and food stuff with Nigella sativa and sesame seeds and eating meals rich in calcium such as dairy products (milk and yoghurt) may be beneficial for the treatment of postmenopausal osteoporosis in women.
\end{abstract}

Keywords: Nigella sativa; Sesame seeds; High-calcium diet; Ovariectomy; Osteoporosis;

Biochemical analysis; Bone mineralization.

\section{Introduction}

Osteoporosis is considered a major public health problem and characterized by bone mass reduction, and decreased bone mineral density leading to an increased risk of bone fragility and fractures (McCarron and Heaney, 2004). The bone matrix is composed of organic (collagen and glycoprotein) and inorganic (minerals mainly calcium and phosphorus) components. Both organic and inorganic components provide strictness and strength to the bones (McNamara et al., 2006). Osteoporosis represents a serious problem among postmenopausal women and menopause drastically increases the risk of osteoporosis (Vassilopoulou-Sellin, 2003 and Canalis et al., 2007). Estrogen deficiency is the main risk factor for postmenopausal osteoporosis because estrogen is most potent inhibitor of osteoclastic bone resorption (Gambacciani and Ciaponi, 2000). Although long term estrogen replacement therapy has 
been commonly used to compensate bone loss, estrogen therapy is usually accompanied with severe adverse or side effects (Al-Anazi et al., 2011).

Nigella sativa (NS) seeds have been used for thousands of years for culinary and medical purposes. Many of the biological activities of NS were attributed to thymoquinone in the oil. (Houghton et al., 1995). The seeds of NS are used worldwide to treat various diseases and ailments. Thymoquinone (TQ) is most abundant and active ingredient of NS essential oil that mediates most of therapeutic effects. TQ was reported to produce antioxidant (Badary et al., 1997); anticancer (Gali-Muhtasib et al., 2006); nephroprotective (Al-Majed et al., 2006); anti-inflammatory (Ragheb et al., 2009) and hypolipidemic and antioxidant effects (Ahmad and Beg, 2013). Animal studies have shown that combination of NS and human parathyroid hormone was effective for the treatment of diabetes-induced osteoporosis and for promotion of fracture healing (Atlan, 2007). The antiosteoporotic effect was attributed to the antioxidant and antiinflammatory activities of NS and TQ because osteoporosis has been linked to oxidative stress and inflammation (Shuid et al., 2012). Moreover, TQ was found to accelerate osteoblast differentiation and activate bone building (Wirries et al., 2013).

Sesame seeds have been used as a source of healthful foods and sesame oil. Sesame seeds are rich source of many essential minerals as calcium, iron, manganese, phosphorous, magnesium, selenium, and copper. These minerals play a vital role in bone mineralization and health. Sesame oil is one of the most stable vegetable oils contains high content of natural antioxidant lignans (sesamin, sesamolin and sesamol). Sesame oil was reported to prevent bone loss in ovariectomized rats (Boulbaroud et al., 2008). Sesamin was reported to activate osteoblast differentiation, to produce an osteoprotective effect and may be a promising phytochemical that could be developed for supplementation of osteoporotic therapy (Wanachenwin et al., 2012).

There is an increasing interest in nutrients which influence bone metabolism and health such as calcium and vitamin D (Ilich and Kerstetter, 2000 and Gourlay, and Brown, 2004). The involvement of oxidative stress in osteoporosis has been shown to be due to insufficient intake of antioxidants, therefore it can increase the risk of hip fracture in smokers (Melhus et al., 1999). The natural polyphenolic antioxidants and flavonoids have been received much attention for their potential role in preventing osteoporosis induced in rats (Draper et al., 1997) and in human (Potter et al., 1998). Flavonoids have been characterized as naturally occurring selective estrogen receptor modulators (SERMs) with beneficial effect on bone heath (Brezinski and Debi, 1999). Flavonoids have been shown to inhibit bone loss in rats, by inhibiting rat osteoclast formation and differentiation and may be useful for the treatment of bone resorption (Jeon et al. 2009; Oka et al.; 2012 and Li et al., 2013).

The present study, aimed to evaluate the effect of diets fortified with Nigella sativa, sesame seeds and high calcium on serum, urinary and bone markers of osteoporosis in ovariectomized rats.

\section{Materials and Methods}

\section{Plant seeds and calcium carbonate}

Nigella sativa (Black Seed, Family Ranunculaceae) and Sesame (Family Pelaliaceae) seeds were purchased from local store of spices, Cairo, Egypt. These seeds were grinded into a fine powder using an electric mixer. Each powder was added to basal diet at a concentration of $10 \%$ to formulate experimental diets.

Calcium carbonate is widely used as an inexpensive dietary calcium supplement. It was purchased from ElGomhoryia Company, Egypt in the form of fine powder packed in brown bottles, of 500 gram each. 


\section{Egypt. J. of Nutrition and Health Vol. 9 No. 1 (2014)}

\section{Rats}

Fifty six mature female Sprague Dawley rats weighing 220-230 g b.wt and 8-10 weeks old were used in this study. The rats were purchased from Laboratory Animal Colony, Helwan, Egypt. The animals were housed individually in metabolic cages under hygienic conditions at room temperature of $25{ }^{\circ} \mathrm{C}$, relative humidity of $50 \%$ and $12 \mathrm{hr}$ light/12 hr dark cycles. The rats were fed on either basal or experimental diets during feeding period and water was provided ad libitum.

\section{Standard drug}

Alendronate (Fosamax ${ }^{\circledR}$, class of bisphosphonates, Merck Sharp and Dohme Company, USA) is widely used for treatment of osteoporosis. It was purchased from a local pharmacy in the form of tablets each contains $70 \mathrm{mg}$ Alendronate sodium. The administered dose $3 \mathrm{mg} / \mathrm{kg}$ b.wt of Alendronate was selected according to Maria et al., (2004).

\section{Basal and experimental diets}

The basal diet was prepared according to the recommended dietary allowances for rats (American Institute of Nutrition, AIN) adjusted by Reeves et al. (1993). Basal diet consisted of $14 \%$ protein, $10 \%$ sucrose, $5 \%$ corn oil, $0.25 \%$ choline chloride, 1\% vitamin mixture(Campbell,1963) , $3.5 \%$ salt mixture (Hegested et al., 1941) and 5\% fibers. The remainder was corn starch up to $100 \%$.

Five experimental diets were formulated as follow:

1- Basal diet fortified with $10 \%$ Nigella sativa (NS) seeds powder

2- Basal diet fortified with $10 \%$ sesame (SS) seeds powder

3- Basal diet fortified with $2 \%$ calcium carbonate ( $\mathrm{CaCO} 3$ ) powder

4- Basal diet fortified with $10 \% \mathrm{NS}+2 \% \mathrm{CaCO} 3$

5- Basal diet fortified with $10 \% \mathrm{SS}+2 \% \mathrm{CaCO} 3$

The above formulated experimental diets were prepared to be contained either $10 \%$ NS or $10 \%$ SS or $2 \%$ CaCO3 or $12 \%$ NS and $\mathrm{CaCO} 3$ or $12 \%$ SS and $\mathrm{CaCO} 3$ and the remainder was corn starch up to $100 \%$.

\section{Ovariectomy procedure}

Under ether anaethesia, the bilateral ovariectomy was performed in rats by making two dorsolateral incisions using sharp dissecting scissors. The skin and dorsal muscles were then cut and the peritoneal cavity was thus reached. The uterine horn was picked out and the fatty tissue around the ovary was removed. The connection between the Fallopian tube and the uterine horn was clamped by artery forceps and cut was made under the clamped area to remove the ovary. Skin was closed bilaterally with one simple catgut suture. Tincture iodine solution (antiseptic) was applied locally on the skin at both sites of the operation (Lasota and Danowska-Klonowska, 2004). Similarly sham operation was performed where the ovaries were exposed, but not removed.

\section{Experiment and feeding of rats}

The rats were randomized into to 8 equal groups of 7 animals each and kept individually in metal metabolic cages. Group (1) was sham-operated (SHAM) and fed on basal diet, while the other 7 groups were ovariectomized (OVX) and left for 3 weeks post-operation to ensure almost complete clearance of their bodies from sex hormone residues. Group (2) was kept OVX (Positive control) and fed on basal diet. Groups(3), (4), (5), (6) and (7) were fed on experimental diets fortified with: (A) 10\% Nigella sativa (NS) powder; (B) $10 \%$ sesame (SS) seeds powder; (C) $2 \%$ calcium carbonate (CaCO3) powder (Agata et al. 2013) ; (D) 10\% NS + 2\% CaCO3 and (E) $10 \% \mathrm{SS}+2 \%$ CaCO3 for 6 weeks, respectively. Group (8) was orally administered Alendronate drug (standard antiosteoporotic) in daily dose of $3 \mathrm{mg} / \mathrm{kg}$ for 6 weeks and fed on basal diet. During feeding period, the initial and final body weights of rats were recorded and changes in weight gains were calculated. The last 24 hour urine samples and blood samples were collected for biochemical analyses. The rats were then euthanized by prolonged exposure to ether anesthetic and uterine horns were dissected out and weighed. Femur bones were dissected out and prepared for bone analysis. 


\section{Reham S. Ramadan}

\section{Biochemical analyses}

Blood samples were withdrawn by cardiac puncture, left standing for 10 minutes to clot and centrifuged at $4000 \mathrm{rpm}$ for 15 minutes to separate the serum which kept frozen at $-18^{\circ} \mathrm{C}$ till biochemical analyses. Urine samples of the last 24 hour were collected, acidified with $12 \mathrm{Mol} \mathrm{HCl}$ and kept in the refrigerator till biochemical analyses. Concentrations of calcium (Gindler and King, 1972) and phosphorus (Goodwin, 1970) in serum and urine samples were colorimetrically determined using specific diagnostic reagent kits (BioMérieux, France) and measured on UV spectrophotometer. Serum bone-specific alkaline phosphate (Nawawi and Girgis, 2002) was estimated by colorimetric assay using specific enzyme kits (Sigma-Aldrich Chemical Co., USA). Serum osteocalcin concentration was measured by enzyme-linked immunosorbent assay (Rat Mid ${ }^{\mathrm{TM}}$, osteocalcin ELISA kit, USA) according to Craciun et al. (2000). Urinary pyridinoline (PD) and deoxypyridinoline (DPD) were measured using high performance liquid chromatography (HPLC). Urinary concentrations of PD and DPD were expressed as $\mu \mathrm{mol} / \mathrm{Mol}$ creatinine according to Ohishi et al. (1993). Creatinine concentration was colorimetrically determined using Jaffe reaction according to the method of Husdan and Rapoport, (1968).

\section{Bone analysis}

After sacrificing the rats, both femurs were dissected out and the soft tissues were removed. Both femur epiphyses were removed and the length of each femur was measured using Vernier caliper. Femur bone volume and density (BMD) were calculated according to principle of Archimedes (Doyle and Cashman, 2003). In brief, the femur was cut out at the mid diaphyses and bone marrow washed out. Each femur bone was placed in a vial filled with deionized water and the vial was placed in vacuum desiccator for 90 minutes. The femurs were removed from the vial, dried by blotted paper, weighed, and placed again in another vial containing deionized water. The bone was reweighed and bone volume was measured. Femur bone density (BMD) was calculated using this formula: BMD = femur weight/femur volume. To obtain the ash, femur bones were dehydrated and defatted in acetone and anhydrous ether, dried for $6 \mathrm{hr}$ in an oven at $700^{\circ} \mathrm{C}$. The remaining ash was weighed, solubilized with $0.1 \mathrm{Mol} / \mathrm{L} \mathrm{HCl}$, transferred into volumetric flask and completed to $100 \mathrm{ml}$ with $0.1 \mathrm{Mol} / \mathrm{L} \mathrm{HCl}$ according to Yang et al. (2008). The final solution was used for estimation of calcium and phosphorus in the ash using colorimetric methods.

\section{Statistical analysis}

Data were presented as means \pm SE. Statistical analysis was performed using computerized Statistical Package of Social Sciences (SPSS) program with one-way analysis of variance (ANOVA) followed by Duncan's multiple range tests according to Snedecor and Cochran (1986).

\section{Results}

The result of analysis of body weight of rats revealed that the OVX rats gained more body weight than sham (SHAM) control rats. The percentage of weight gain was $18.00 \%$ in OVX control group versus to $11.96 \%$ in SHAM control group. Ovariectomy in rats caused a significant $(P<0.05)$ decrease in uterine weight when compared with SHAM control group. The mean value \pm SE of uterine weight was $0.45 \pm 0.01 \mathrm{~g}$ in OVX control rats versus to $1.20 \pm 0.04 \mathrm{~g}$ in SHAM control rats and $0.99 \pm 0.02 \mathrm{~g}$ in Alendronate-treated rats. Feeding of OVX rats on diets fortified with Nigella sativa, sesame seeds and high calcium significantly reduced weight gain and increased uterine weight when compared to the OVX control group (Table 1). 
Table 1.

Effect of diets fortified with Nigella sativa (NS), sesame seeds (SS) and high calcium carbonate $(\mathrm{CaCO} 3)$ on body weight gain and uterine weight in ovariectomized (OVX) rats.

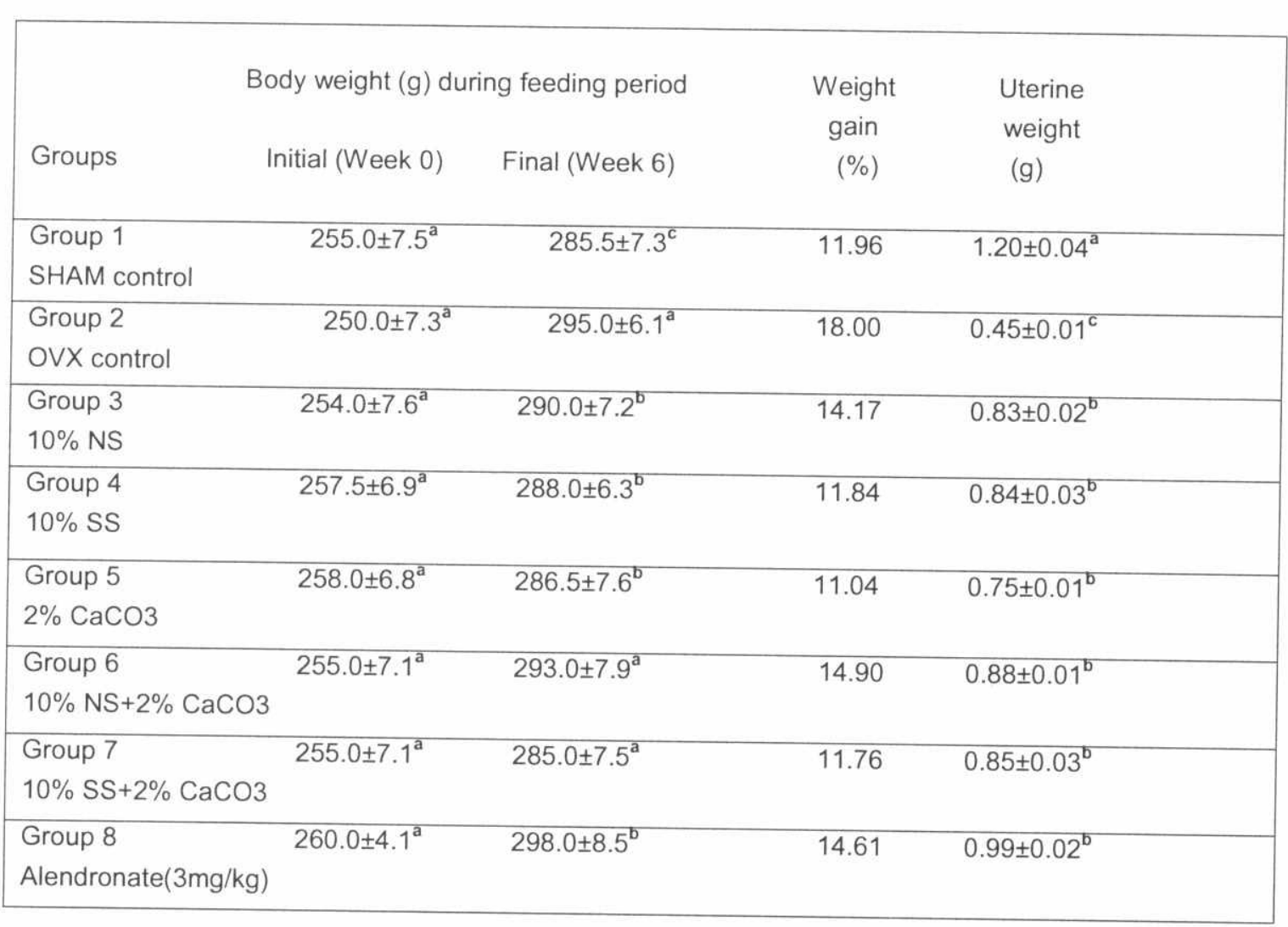

Means \pm SE with different superscript letters in the same column are significant at $P<0.05$ using one way ANOVA test, $\mathrm{n}=7$ rats in each group.

Bilateral ovariectomy in rats caused significant $(P<0.05)$ increases in serum levels of calcium (Ca), phosphorous (P), bone-specific alkaline phosphatase (b-ALP) and osteocalcin (OC) when compared with the SHAM control group. Experimental diets fortified with Nigella sativa, sesame seeds and high calcium significantly $(P<0.05)$ decreased the elevated serum levels of $\mathrm{Ca}, \mathrm{P}, \mathrm{b}-\mathrm{ALP}$ and $\mathrm{OC}$ in OVX rats when compared to the OVX (positive) control group as recorded in Table (2). 
Table 2.

Effect of diets fortified with Nigella sativa (NS), sesame seeds (SS) and high calcium carbonate $(\mathrm{CaCO} 3)$ on serum calcium $(\mathrm{Ca})$, phosphorous $(\mathrm{P})$, bone specific alkaline phosphatase $(\mathrm{b}-\mathrm{ALP})$ and osteocalcin $(O C)$ in ovariectomized (OVX) rats.

\begin{tabular}{|c|c|c|c|c|}
\hline Groups & $\begin{array}{c}\mathrm{Ca} \\
(\mathrm{mg} / \mathrm{dL})\end{array}$ & $\begin{array}{c}\mathrm{P} \\
(\mathrm{mg} / \mathrm{dL})\end{array}$ & $\begin{array}{l}\text { b-ALP } \\
(U / L)\end{array}$ & $\begin{array}{c}\mathrm{OC} \\
(\mu \mathrm{g} / \mathrm{L})\end{array}$ \\
\hline $\begin{array}{l}\text { Group } 1 \\
\text { SHAM control }\end{array}$ & $10.90 \pm 0.3^{b}$ & $3.65 \pm 0.1^{b}$ & $125.0 \pm 4.7^{\mathrm{d}}$ & $10.6 \pm 0.01^{d}$ \\
\hline $\begin{array}{l}\text { Group } 2 \\
\text { OVX control }\end{array}$ & $13.20 \pm 0.6^{\mathrm{a}}$ & $6.15 \pm 0.2^{a}$ & $179.5 \pm 7.2^{a}$ & $15.2 \pm 0.03^{\mathrm{a}}$ \\
\hline $\begin{array}{l}\text { Group } 3 \\
10 \% \text { NS }\end{array}$ & $11.50 \pm 0.3^{b}$ & $4.77 \pm 0.2^{\mathrm{b}}$ & $158.5 \pm 7.4^{b}$ & $13.6 \pm 0.01^{b}$ \\
\hline $\begin{array}{l}\text { Group } 4 \\
10 \% \text { SS }\end{array}$ & $11.60 \pm 0.2^{b}$ & $4.80 \pm 0.1^{b}$ & $156.6 \pm 7.6^{b}$ & $13.4 \pm 0.02^{b}$ \\
\hline $\begin{array}{l}\text { Group } 5 \\
2 \% \mathrm{CaCO} 3\end{array}$ & $11.70 \pm 0.3^{b}$ & $4.85 \pm 0.3^{b}$ & $153.6 \pm 6.5^{b}$ & $13.2 \pm 0.03^{b}$ \\
\hline $\begin{array}{l}\text { Group } 6 \\
10 \% \text { NS }+2 \% \text { CaCO3 }\end{array}$ & $10.70 \pm 0.5^{b}$ & $3.66 \pm 0.4^{b}$ & $135.6 \pm 5.2^{c}$ & $11.5 \pm 0.03^{c}$ \\
\hline $\begin{array}{l}\text { Group } 7 \\
10 \% \text { SS }+2 \% \mathrm{CaCO} 3\end{array}$ & $10.77 \pm 0.4^{b}$ & $3.55 \pm 0.3^{b}$ & $138.6 \pm 6.2^{c}$ & $11.3 \pm 0.03^{c}$ \\
\hline $\begin{array}{l}\text { Group } 8 \\
\text { Alendronate }(3 \mathrm{mg} / \mathrm{kg})\end{array}$ & $10.65 \pm 0.2^{b}$ & $3.45 \pm 0.4^{b}$ & $135.6 \pm 8.5^{c}$ & $10.8 \pm 0.02^{c}$ \\
\hline
\end{tabular}

Means \pm SE with different superscript letters in the same column are significant at $P<0.05$ using one way ANOVA test, $\mathrm{n}=7$ rats in each group.

The analysis of the last 24 hour urine samples showed that ovariectomy in rats caused high significant $(P<$ 0.001 ) increases of urinary excretion $\mathrm{Ca}$ and $\mathrm{P}$ when compared to the SHAM control group. Experimental diets fortified with Nigella sativa (NS), sesame (SS) seeds and high calcium when fed to OVX rats and oral administration of drug Alendronate to OVX rats significantly $(P<0.05$ to $P<0.001)$ decreased urinary excretion of $\mathrm{Ca}$ and $\mathrm{P}$ when compared to OVX rats as demonstrated in Fig. (1). Similarly, diets fortified with NS, SS and high calcium and oral administration of Alendronate significantly $(P<0.05$ to $P<0.01)$ decreased urinary excretion of pyridinoline $(P D)$ and deoxypyridinoline (DPD) as illustrated in Fig. (2). 


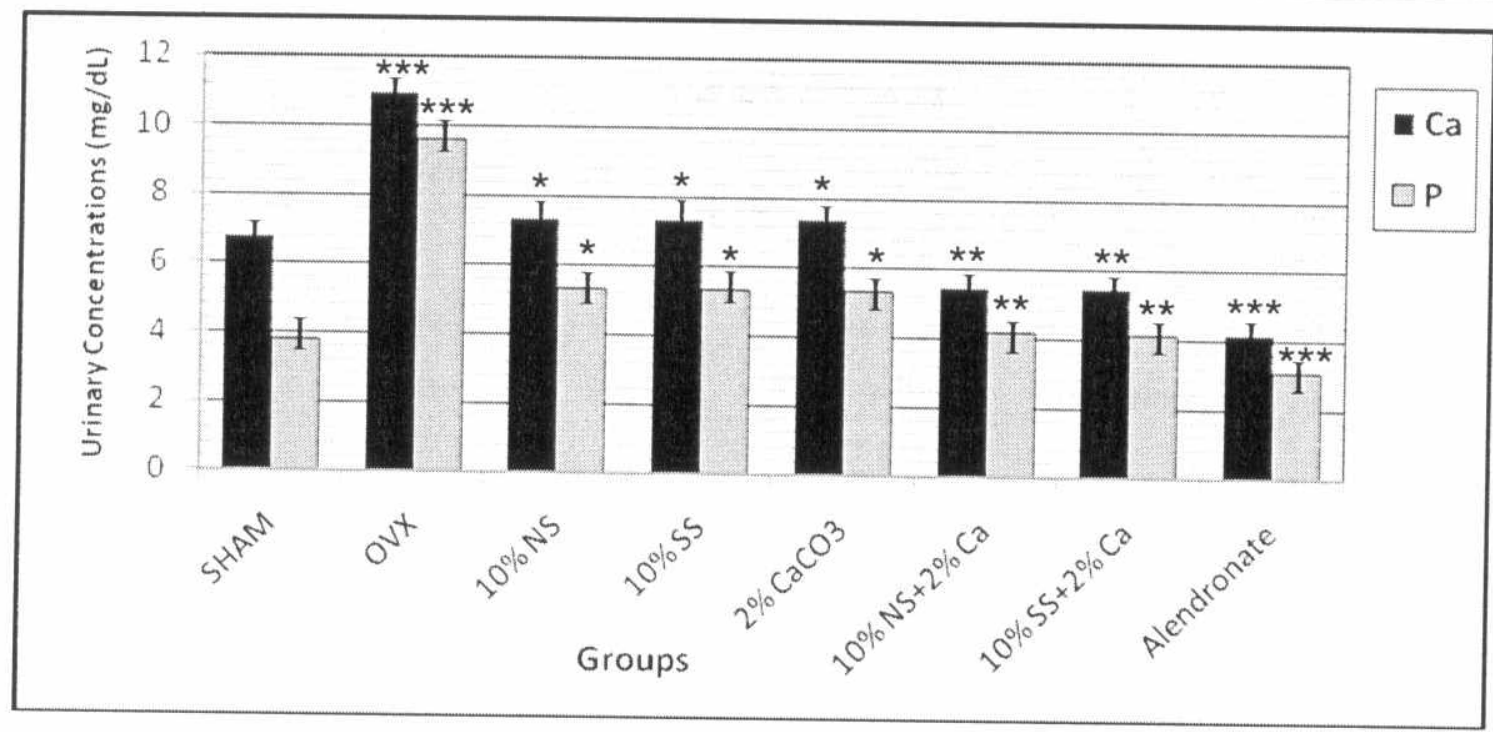

Fig. (1). Effect of diets fortified with Nigella sativa (NS), sesame seeds (SS) and high calcium carbonate (CaCO3) on urinary excretion of calcium (Ca) and phosphorus $(P)$ in ovariectomized $(\mathrm{OVX})$ rats.

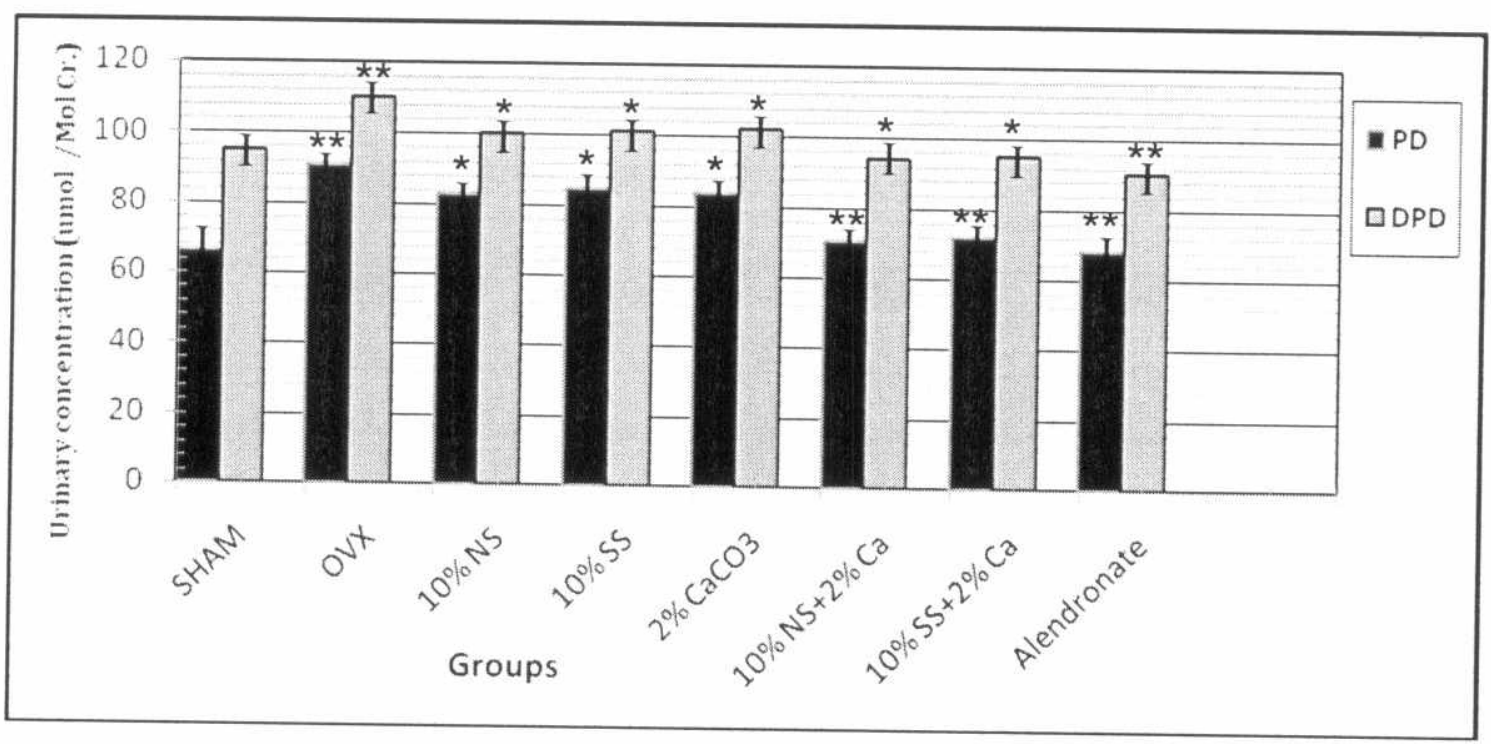

Fig. 2. Effect of diets fortified with Nigella sativa (NS), sesame seeds (SS) and high calcium carbonate (CaCO3) on urinary excretion of pyridinoline (PD) and deoxypyridinoline (DPD) in ovariectomized (OVX) rats.

Data in Table (3) showed that bilateral ovariectomy in rats induced significant $(P<0.05)$ decreases in femur weight and bone mineral density (BMD) when compared to the SHAM control group. Feeding of OVX rats on diets fortified with Nigella sativa seeds, sesame seeds and high calcium restored the ovariectomy-induced decreases in femur weight and BMD when compared to the OVX control group. Alendronate drug (standard) increased femur weight and BMD when compared to the OVX control group. No significant changes in femur length and volume between control and experimental groups were observed. 
Table 3.

Effect of diets fortified with Nigella sativa (NS), sesame seeds (SS) and high calcium carbonate $(\mathrm{CaCO} 3$ ) on femur weight (Wt), length (L), volume (V) and bone mineral density (BMD) in ovariectomized (OVX) rats.

\begin{tabular}{|c|c|c|c|c|}
\hline Groups & $\begin{array}{l}\text { Femur Wt. } \\
\text { (g) }\end{array}$ & $\begin{array}{l}\text { Femur L } \\
(\mathrm{mm})\end{array}$ & $\begin{array}{l}\text { Femur } \mathrm{V} \\
\left(\mathrm{cm}^{3}\right)\end{array}$ & $\begin{array}{l}\mathrm{BMD} \\
\left(\mathrm{g} / \mathrm{cm}^{3}\right)\end{array}$ \\
\hline $\begin{array}{l}\text { Group } 1 \\
\text { SHAM control }\end{array}$ & $1.65 \pm 0.01^{a}$ & $45.01 \pm 3.75^{a}$ & $0.68 \pm 0.02^{a}$ & $2.43 \pm 0.06^{\mathrm{a}}$ \\
\hline $\begin{array}{l}\text { Group } 2 \\
\text { OVX control }\end{array}$ & $0.88 \pm 0.03^{\mathrm{d}}$ & $43.09 \pm 3.71^{\mathrm{a}}$ & $0.67 \pm 0.03^{\mathrm{a}}$ & $1.31 \pm 0.02^{\mathrm{d}}$ \\
\hline $\begin{array}{l}\text { Group } 3 \\
10 \% \text { NS }\end{array}$ & $1.30 \pm 0.01^{c}$ & $44.10 \pm 3.25^{\mathrm{a}}$ & $0.66 \pm 0.01^{\mathrm{a}}$ & $1.96 \pm 0.03^{c}$ \\
\hline $\begin{array}{l}\text { Group } 4 \\
10 \% \text { SS }\end{array}$ & $1.33 \pm 0.03^{c}$ & $43.15 \pm 3.15^{a}$ & $0.67 \pm 0.02^{a}$ & $1.98 \pm 0.02^{c}$ \\
\hline $\begin{array}{l}\text { Group } 5 \\
2 \% \mathrm{CaCO} 3\end{array}$ & $1.32 \pm 0.02^{c}$ & $45.10 \pm 3.05^{a}$ & $0.68 \pm 0.04^{a}$ & $1.94 \pm 0.03^{c}$ \\
\hline $\begin{array}{l}\text { Group } 6 \\
10 \% \mathrm{NS}+2 \% \mathrm{CaCO} 3\end{array}$ & $1.40 \pm 0.06^{b}$ & $43.10 \pm 2.05^{\mathrm{a}}$ & $0.69 \pm 0.03^{a}$ & $2.02 \pm 0.01^{b}$ \\
\hline $\begin{array}{l}\text { Group } 7 \\
10 \% \mathrm{SS}+2 \% \mathrm{CaCO} 3\end{array}$ & $1.45 \pm 0.04^{b}$ & $44.10 \pm 1.90^{\mathrm{a}}$ & $0.67 \pm 0.02^{a}$ & $2.12 \pm 0.02^{b}$ \\
\hline $\begin{array}{l}\text { Group } 8 \\
\text { Alendronate }(3 \mathrm{mg} / \mathrm{kg})\end{array}$ & $1.55 \pm 0.01^{b}$ & $45.10 \pm 2.55^{\mathrm{a}}$ & $0.68 \pm 0.01^{a}$ & $2.28 \pm 0.01^{\mathrm{b}}$ \\
\hline
\end{tabular}

Means \pm SE with different superscript letters in the same column are significant at $P<0.05$ using one way ANOVA test, $n=7$ rats in each group.

Bilateral ovariectomy in rats produced significant $(P<0.05)$ decreases in weights of femur ash and calcium level in bone ash when compared to the SHAM control group. No significant changes in ash phosphorous content between control and experimental groups were found. Experimental diets fortified with Nigella sativa, sesame seeds and high calcium normalized weights of femur, ash, and calcium content in the ash. Alendronate drug also increased weights of femur, ash, and calcium content in the ash when compared to the OVX control group as depicted in Table (4). 


\section{Egypt. J. of Nutrition and Health Vol. 9 No. 1 (2014)}

Table 4.

Effect of diets fortified with Nigella sativa (NS), Sesame seeds (SS) and high calcium carbonate $(\mathrm{CaCO} 3)$ on femur ash weight and calcium $(\mathrm{Ca})$ and phosphorous $(\mathrm{P})$ ash levels in ovariectomized $(\mathrm{OVX})$ rats.

\begin{tabular}{|c|c|c|c|}
\hline Groups & $\begin{array}{l}\text { Ash Wt. } \\
\text { (g) }\end{array}$ & $\begin{array}{c}\mathrm{Ca} \\
\text { (mg/g ash) }\end{array}$ & $\begin{array}{c}\mathrm{p} \\
(\mathrm{mg} / \mathrm{g} \text { ash })\end{array}$ \\
\hline $\begin{array}{l}\text { Group } 1 \\
\text { SHAM control }\end{array}$ & $0.95 \pm 0.03^{\mathrm{a}}$ & $12.5 \pm 0.02^{\mathrm{a}}$ & $7.42 \pm 0.12^{a}$ \\
\hline $\begin{array}{l}\text { Group } 2 \\
\text { OVX control }\end{array}$ & $0.60 \pm 0.01^{\mathrm{d}}$ & $6.5 \pm 0.01^{d}$ & $7.41 \pm 0.13^{\mathrm{a}}$ \\
\hline $\begin{array}{l}\text { Group } 3 \\
10 \% \text { NS }\end{array}$ & $0.77 \pm 0.01^{c}$ & $8.2 \pm 0.03^{c}$ & $7.42 \pm 0.14^{\mathrm{a}}$ \\
\hline $\begin{array}{l}\text { Group } 4 \\
10 \% \text { SS }\end{array}$ & $0.78 \pm 0.03^{c}$ & $9.0 \pm 0.01^{c}$ & $7.43 \pm 0.11^{\mathrm{a}}$ \\
\hline $\begin{array}{l}\text { Group } 5 \\
2 \% \mathrm{CaC} 03\end{array}$ & $0.79 \pm 0.03^{c}$ & $9.2 \pm 0.02^{c}$ & $7.42 \pm 0.10^{\mathrm{a}}$ \\
\hline $\begin{array}{l}\text { Group } 6 \\
10 \% \text { NS }+2 \% \mathrm{CaCO} 3\end{array}$ & $0.84 \pm 0.02^{b}$ & $10.6 \pm 0.02^{b}$ & $7.40 \pm 0.12^{\mathrm{a}}$ \\
\hline $\begin{array}{l}\text { Group } 7 \\
10 \% \text { SS }+2 \% \text { CaC03 }\end{array}$ & $0.88 \pm 0.02^{b}$ & $11.9 \pm 0.03^{b}$ & $7.41 \pm 0.13^{a}$ \\
\hline $\begin{array}{l}\text { Group } 8 \\
\text { Alendronate }(3 \mathrm{mg} / \mathrm{kg})\end{array}$ & $0.92 \pm 0.03^{b}$ & $12.1 \pm 0.02^{b}$ & $7.44 \pm 0.10^{a}$ \\
\hline
\end{tabular}

Means \pm SE with different superscript letters in the same column are significant at $P<0.05$ using one way ANOVA test, $n=7$ rats in each group. 


\section{Discussion}

The present study aimed to evaluate the effect of diets fortified with Nigella sativa, sesame seeds and high calcium on serum, urinary and bone markers of osteoporosis in ovariectomized (OVX) rats.

Estrogen is the most potent inhibitor of osteoclastic bone resorption (loss), so estrogen deficiency is a major risk factor in the pathogenesis of osteoporosis (Gambacciani and Ciaponi, 2000). Bilateral ovariectomy in rats caused dramatic decreases in uterine weight, bone mineral content, density and biomechanical strength due to estrogen deficiency (Mori-Okamoto, et al., 2004; Coxam, 2005; Srikanta et al., 2011 and Zhang et al., 2013). Postmenopausal osteoporosis is commonly treated by estrogen replacement therapy and/or by some drugs such as Alendronate (one of Bisphosphonates series) which inhibits osteoclast-mediated bone resorption (Srikanta et al., 2011).

Free radicals are known to be the main cause of oxidative stress which is grossly implicated in the pathogenesis of various diseases such as cancer, diabetes, cardiovascular diseases, and osteoporosis. Natural antioxidants have gained much attention from consumers because they are considered safer than synthetic antioxidants. Natural antioxidants derived from fruits, vegetables, spices, and cereals are very effective and can protect the human body from oxidative stress caused by ROS (Sreeramulu and Raghunath, 2010).

Results of the present study showed that diets fortified with Nigella sativa, sesame seeds and high calcium prevented the increase in weight gain and the decrease in uterine weight in ovariectomized rats and turned the changes in body and uterine weights to near the normal weights of SHAM-operated rats. Estrogen was reported to increase the vascularity, growth and weight of the uterus in immature rats and mice (Shalaby, 1977). The decreased weight in uterus induced by ovariectomy could be attributed to estrogen deficiency in OVX rats. This finding was previously also reported by Srikanta et al. (2011) who found that bilateral ovariectomy in rats significantly increased body weight and decreased uterine weight. The increases in body weight gain and serum levels of bone- specific alkaline phosphatase (b-ALP) and osteocalcin (OC) in OVX rats, reported in this study, were similar to the previously reported by Ke et al. (1997); Tamir et al. (2001); Coxam (2005) and Srikanta et al. (2011) who concluded that increases in body weight gain and serum bALP and OC are due to estrogen deficiency in OVX rats and mice. Serum b-ALP and OC are commonly used as biochemical markers of bone formation. Serum high levels of b-ALP and OC after feeding diets fortified with Nigella sativa, sesame seeds and high calcium could be possibly due to an increased osteoblastic activity (Srikanta et al. (2011).

Calcium, vitamin D, and parathyroid hormone are critical regulators of bone remodeling (Lu et al., 2013). Calcium and phosphorus are widely used as markers for bone formation as they have a vital role in bone mineralization (Evans et al., 1990 and Choi and Seo, 2013). In the present study, the bilateral ovariectomy increased serum calcium and phosphorus levels as compared to sham-operated rats. The decreases in serum calcium and phosphorous levels were reported to be due to estrogen deficiency in ovariectomized rats (Choi and Seo, 2013). Diets fortified with Nigella sativa and sesame seed and high calcium reduced serum calcium levels denoting that calcium may be deposited in bones, so increasing bone mineral density and calcium content in bone ash.

The results of urine analysis showed that bilateral ovariectomy in rats increased urinary excretion of calcium, phosphorous, pyridinoline (PD) and deoxypyridinoline (DPD). Feeding of diets fortified with Nigella sativa, sesame seed and high calcium decreased urinary excretion of $\mathrm{Ca}, \mathrm{P}, \mathrm{PD}$ and $\mathrm{DPD}$ in OVX rats. Urinary pyridinoline (PD) and deoxypyridinoline (DPD) are commonly used as biochemical markers of bone resorption (loss). Urinary PD and DPD were found to be released into the blood during bone degradation and rapidly excreted in the urine (Samma et al. 1997). The values of urinary PD and DPD were significantly higher in females than in males and increased in the urine during early postmenopausal period (Ohishi et al., 1993). In rats fed on diet fortified with $10 \%$ sesame seeds, the decreased 


\section{Egypt. J. of Nutrition and Health Vol. 9 No. 1 (2014)}

urinary excretion of PD and DPD, reported in this study, denoted that these seeds could prevent bone loss in OXV rats. This finding was partially similar to that reported by Boulbaroud et al., (2008) who concluded that sesame oil can prevent bone loss in ovariectomized rats. Sesamin a major lignan compound in sesame oil was reported to produce an osteoprotective effect (Wanachenwin et al., 2012).

The mechanism(s) of anti-osteoporotic activity of Nigella sativa seeds could be due to antioxidant and antiinflammatory effects of thymoquinone partly via modulation of osteoblast maturation because osteoporosis has been positively linked to the oxidative stress and inflammation (Shuid et al., 2012). Other mechanism may be due to high contents of polyphenolic and flavonoid compounds in Nigella sativa (Draper et al., 1997) and in human (Potter et al., 1998).

The anti-osteoporotic effect of sesame seeds could be due to presence of high contents of essential minerals especially calcium and phosphorous which play a vital role in bone mineralization. Sesame seeds also contain high contents of natural antioxidant lignans which prevent bone loss in ovariectomized rats (Boulbaroud et al., 2008). In addition, high calcium plus vitamin D3 diet was reported to play a vital role in bone mineralization and so preventing osteoporosis (Chen et al., 2013).

In conclusion, the results denote that diets fortified with Nigella sativa, sesame seeds and high calcium has an anti-osteoporotic effect in ovariectomized rats. The study suggests that Nigella sativa and sesame seeds appear to be promising natural food supplements for the treatment of osteoporosis. Therefore, the study recommends enrichment of the bakeries and food stuff with Nigella sativa and sesame seeds and eating meals rich in calcium such as dairy products (milk and yoghurt) may be beneficial for the treatment of postmenopausal osteoporosis in women. In addition, isolation of bioactive constituents from Nigella sativa and sesame seeds is necessary to search for safe and bioactive natural substances that could be developed for osteoporotic therapy.

\section{Acknowledgement}

My deep grateful acknowledgement is expended to Prof. Dr. Mostafa Abbas Shalaby, Professor of Pharmacology, Faculty of Veterinary Medicine, Cairo University for his co-operation, and assistance in ovariectomy surgical procedure. 


\section{References}

Agata, U.; Park, J.H.; Hattori, S.; Limura, Y.; Ezawa, I.; Akimoto, T. and Omi, N. (2013):

The effect of different amounts of calcium intake on bone metabolism and arterial calcification in ovariectomized rats. J. Nutri. Sci. Vitaminol.; 59(1): 29-36.

Ahmad, S. and Beg, Z.H. (2013):

Hypolipidemic and antioxidant activities of Thymoquinone and limonene in atherogenic suspension fed rats. Food Chem.; 2013 Jun 1; 138(3):1116-1124. Doi: 10.1016/j.foodchem.2012.11.109.

Al-Anazi, A.F.; Qureshi. V.F.; Javaid, K. and Qureshi, S. (2011):

Preventive effects of Phytoestrogens against postmenopausal osteoporosis as compared to the available therapeutic choices: an overview. J. Nat. Sci. Biol. Med.; 2(2):154-163.

Al-Majed, A.A.; Al-Omar, F.A. and Nagi, M.N. (2006):

Neuroprotective effects of Thymoquinone against transient forebrain ischemia in the rat hippocampus. Europ. J. Pharmacol.; 543 (3):40-47. Atlan, M.F. (2007): Effects of Nigella sativa and human parathyroid hormone on bone mass and strength in diabetic rats. Biol. Trace Elem. Res.; 116(3): 321-328.

Badary, OA; Nagi, MN; Al-Shabanah, OA; AI-Sawaf, HA; Al-Sohaibani, MO; Al- Bekairi, A.M. (1997):

Thymoquinone ameliorates the nephrotoxicity induced by cisplatin in rodents and potentiates its antitumor activity. Canadian J. Physiol. Pharmacol.; 75 (12): 1356-1361.

Boulbaroud, S.; Mesfioui, A.; Arfaoui, A.; Quichou, A. and El-Hessni, A. (2008):

Preventive effects of flaxseed and sesame oil on bone loss in ovariectomized rats. Pak. J. Biol. Sci.; 11(13): 16961701.

Brezinski, A. and Debi, A. (1999):

Phytoestrogens: the natural selective estrogen receptor modulators. Eur. J. Obstet. Gynecol. Reprod. Biol.; $85: 47-51$.

Campbell, J. A, (1963): Methodology of protein evaluation RAG Nutri. Document R. 101 Ed, 37 Jun. Meeting, New York.

Canalis, E.; Giustina, A. and Bilezikian, J.P. (2007): Mechanisms of anabolic therapies or osteoporosis. N. Engl. J. Med.; 357(9): 905-916.

Chen, X.; Zhang, L.; Yang, X.; Li, Z.; Sun, X.; Lin, M.; Yang, G. and Gou, Z. (2013): Micronutrients-incorporated calcium phosphate particles with protective effect on osteoporotic bone tissue. J. Nutri. Health Aging; $17(5): 426-433$.

Choi, M.J. and Seo, J.N. (2013):

Effect of taurine feeding on bone mineral density and bone markers in rats. Adv. Exp. Biol. Med.; 776: 51-58

Coxam, V. (2005):

New advances in osteoporosis nutritional prevention. J. Med. Sci.; 21(3): 297-301. 


\section{Egypt. J. of Nutrition and Health Vol. 9 No. 1 (2014)}

Craciun, A.M.; Vermeer, C.; Eisenwiener, H.G.; Drees, N. and Knapen, M.H. (2000):

Evaluation of a bead-based enzyme immunoassay for the rapid detection of osteocalcin in human serum. Clin. Chem.; 46(2):252-257.

Doyle, L. and K.D. Cashman, (2003):

The effect of nutrient profiles of the dietary approaches to stop hypertension diets on blood pressure and bone metabolism and composition in normotensive and hypertensive rats. Br. J. Nutri.; 89: 713- 724.

Draper, C.R.; Edel, M.J.; Dick, I.M., Randall, A.G.; Martin, G.B. and Prince, R.L. (1997):

Phytoestogens reduce bone loss and bone resorption in ovariectomized rats. J. Nutr.; 127: 1795-1799.

Evans, D.B.; Bunning, R.A. and Russell, R.G. (1990):

The effects of recombinant human interleukin-1 $\beta$ on cellular proliferation and the production of prostaglandin E2, plasminogen activator, osteocalcin and alkaline phosphatase by osteoblast-like cells derived from human bone. Biochem. Biophys. Res. Commun.; 166: 208-216.

Gambacciani, M. and Ciaponi, M. (2000):

Postmenopausal osteoporosis management. Curr. Opin. Obestet. Gynecol.; 12(3): 189-197.

Gali-Muhtasib, H.; Roessner, A. and Schneider-Stock, R. (2006):

Thymoquinone: a promising anti-cancer drug from natural sources. Int. J. Biochem. Cell Biol.; 38 (8):1249-1253.

Gindler, E. M. and King, J. D. (1972):

Rapid colorimetric determination of calcium in biologic fluid with methyl thymol blue. Am. J. Clin. Pathol.; 58: $376-$ 382.

Goodwin, J.F. (1970):

Determination of serum phosphorus. Clin. Chem.; 16(9): 776- 780.

Gourlay, M.L. and Brown, S.A. (2004):

Clinical considerations in premenopausal osteoporosis. Arch. Intern. Med.; 164: 603-614.

Hegsted, D. M; Mills, R. C; Elvehjim, C. A; and Hart E. B, (1941):

Salt mixture ,J. Biol, Chem., 138, 149-150.

Houghton, P.J.; Zarka, R.; De-las, H. B.; and Hoult, J.R. (1995):

Fixed oil of Nigella sativa and derived thymoquinone inhibit eicosanoid generation in leukocytes and membrane lipid peroxidation. Planta Medica; 61(1):33-36.

Husdan, H. and Rapoport, A. (1968):

Estimation of creatinine by Jaffe reaction method. Clin. Chem.; 14: 222-228.

Ilich, J.Z. and Kerstetter, J.E. (2000):

Nutrition in bone health: A story beyond calcium. J. Am. Coll. Nutr.; 19: 715-737.

Jeon, B.J.; Ahn, J. and Kwak, H.S. (2009):

Effect of isoflavone-enriched milk on bone mass in ovariectomized rats. J. Med. Food; 12(6):1260-1267. 
Ke, H.Z.; Chen, H.K.; Simmons, H.A.; Crawford. D.T.; Chidsey-Frink. K.L.; Jee, W.S. and Thompson, D.D. (1997): Comparative effects of droloxifene, tamoxifen and estrogen on bone, serum cholesterol, and uterine histology in the ovariectomized rats. Bone; 20: 31-39.

Lasota, A. and Danowska-Klonowska, D. (2004):

Experimental osteoporosis: different methods of ovariectomy in female white rats. Ann. Acad. Med..; 49: 129-131.

Li, N.; Jiang, Y.; Wooly, P.H. Xu, Z. and Yang, S.Y. (2013):

Naringin flavonoid promotes osteoblast differentiation and effectively reverses ovariectomy-associated osteoporosis. J. Orthop. Sci.; 18(3):478-485. Doi: 10.1007/s00776-013-0362-9.

Lu, M.; Famebo, L.O.; Branstrom, R. and Larsson (2013):

Inhibition of parathyroid hormone secretion by caffeine in human parathyroid cells. J. Clin. Endocrinol. Metab.; 98(8): 1345-1351. Doi: 10.1210/jc.2013-1466. Epub 2013 Jun 20.

Maria, P.; llona, K.; Leszek, S.; Waldemar, J. and Rymkiewicz, I. (2004):

Effect of concurrent administration of Alendronate sodium and retinol on development of changes in histomorphometric parameters on bone by ovariectomy in rats. Pol. J. Pharmacol.; 56571-579.

Melhus, H.; Michelson, K.; Holmberg, L.; Wolk, A. and Ljunghall, S. (1999):

Smoking, antioxidant vitamins and risk of hip fracture. J. Bone Miner. Res.; 14: 129-135.

McCarron, D.A. and Heaney, R.P. (2004):

Estimated healthcare savings associated with adequate dairy food intake. Am. J. Hypertens.; 17: 88-97.

McNamara, L.M.; Ederveen, A.G.; Lynos, C.G.; Schaffler, M.B.; Weinans, H. and Prendergast, P.J. (2006):

Strength of cancellous bone trabecular tissue from normal, ovariectomized and drug-treated rats over the course of aging. Bone; 39(2): 392-400.

Mori-Okamoto, J.; Otawara- Hamamoto, Y.; Yamato, H. and Yoshimura, H. (2004):

Pomegranate extract improves a depressive state and bone properties in menopause syndrome model ovariectomized mice. J. Ethnopharmacol.; 92: 93-101.

Nawawi, H. and Girgis, S.I. (2002):

Serum levels of bone-specific alkaline phosphatase and procollagen carboxyterminal peptide in vitamin D deficiency.

Asian J. Trop. Med. Public Health; 33: 124-130.

Ohishi, T.; Takahashi, M.; Kawana, K.; Aoshima, H.; Hoshino, H.; Horiuchi, K.; Kushida, K. and Inoue, T. (1993):

Age-related changes of urinary pyridinoline and deoxypyridinoline in Japanese subjects. Clin. Invest. Med.; 16(5): 319-125.

Oka, Y.; Iwai, S.; Amano, H.; Irie, Y.; Yatomi, K. and Oguchi, K. (2012):

Tea polyphenols inhibit rat osteoclast formation and differentiation. J. Pharmacol. Sci.; 118(1):55-64. 


\section{Egypt. J. of Nutrition and Health Vol. 9 No. 1 (2014)}

Potter, S.M.; Baum, J.A.; Teng, H.; Stillman, R.J.; Shays, N.F. and Erdman, J.W. (1998):

Soy protein and isoflavones: their effects on blood lipids and bone density in postmenopausal women. Am. J. Clin. Nutri.; 68(6):1375S-1379S.

Ragheb, A.; Attia, A.; Eldin, W.S.; Elbarbry, F.; Gazarin, S. and Shoker, A. (2009):

The protective effect of thymoquinone, an anti-oxidant and anti-inflammatory agent, against renal injury: a review. Saudi J. Kid. Dis. Transpl.; 20(5):741-752.

Reeves, P.G.; Nielson, F.H. and Fahmy, G.C. (1993):

Reports of the American Institute of Nutrition, Adhoc willing committee on reformulation of the AIN 93, rodent diet. J. Nutri.; 123: 1939-1951.

Samma, S.; Kagebayashi, Y. and Yasukawa, M. (1997):

Sequential changes of urinary pyridinoline and deoxypyridinoline as markers of metastatic bone tumor in patients with prostate cancer: A preliminary study. Japanese J. Clin. Oncol.; 27:26-30.

Shalaby, M.A. (1977):

Pharmacological studies on sex hormone- like effects of some Egyptian leguminous plants with their action on the uterus. MVSc. Thesis submitted to Pharmacology Department, Faculty of Veterinary Medicine, Cairo University. Egypt.

Shuid, A.N.; Mohamed, N.; Mohamed, I.N.; Othman, F.; Suhaimi, F. and Soeliaiman. I.N. (2012):

Nigella sativa: A potential antiosteoporotic agent. Evid. Based Complement. Alternat. Med., 2012:696230. Doi: $10.1155 / 2012 / 696230$

Snedecor, G.W. and Cochran, W.G. (1986):

Statistical Methods, $7^{\text {th }}$ Edition, lowa State University Press, Ames, USA, Page 90.

Sreeramulu, D. and Raghunath. M. (2010):

Antioxidant activity and phenolic content of roots, tubers and vegetables commonly consumed in India. Food Res Int.; 43:1017-1020.

Srikanta, P.; Nagarajappa, S. H.; Viswanatha, G.L.; Handral, M.; Subbanna, R.; Srinath, R.; Hiremath, G. (2011): Anti-osteoporotic activity of methanol extract of an Indian herbal formula (NR/CAL/06) in ovariectomized rats. J. Chinese Integr. Med.; 9(10): 1125-1132.

Tamir, S.; Eizenberg, M.; Somjen, D.; Izrael, S. and Vaya J. (2001):

Estrogen-like activity of glabrene and other constituents isolated from licorice root. J. Steroid Biochem. Mol. Biol.; 78(3): 291-298

Vassilopoulou-Sellin, R. (2003):

Breast cancer and hormonal replacement therapy. Ann. N.Y. Acad. Sci.; 997:341-350.

Wanachenwin, O.; Boonmaleerat, K.; Pothacharoen, P. Reutrakul, V. and Kongtawelert, P. (2012):

Sesamin stimulates osteoblast differentiation through p38 and ERK1/2 MAPK signaling pathways. Complement. Alternat. Med.; 2012 May 30; 12:71. Doi: 10.1186/1472-6882-12-71. 
Wirries, A.; Schubert, A.K.; Zimmermann, R., Jabari, S.; Ruchholtz, S. and EI-Najjar, N. (2013):

Thymoquinone accelerates osteoblast differentiation and activates bone morphogenetic protein-2 and ERK pathway. Int. Immunopharmacol.; 15(2):381- 386.

Yang, L.; Wu, J.; Ho, L.; Yang, G. S.; Hung, Y. and Lin, W. (2008):

Effect of poly- (a glutamic acid on calcium absorption in rats. Biosci. Biotechnol. Biochem.; 72: 3084-3090.

Zhang, L.Z.; Xin, J.J.; Zhang, X.P.; Fu, Q.; Zhang, Y. and Zhou, Q.L. (2013):

The anti-osteoporotic effect of velvet antler polypeptides from Cervus elaphus Linnaeus in ovariectomized rats. J. Ethnopharmacol.; 150: 181-186. 
Egypt. J. of Nutrition and Health Vol. 9 No. 1 (2014)

$$
\begin{aligned}
& \text { تأثير الوجبات الغذائية المدعمة بحبة البركة وبذور السمسم وتركيز عال من الكالسيوم }
\end{aligned}
$$

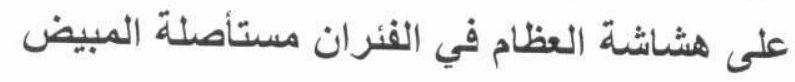

$$
\begin{aligned}
& \text { ريهام شوقى رمضان } \\
& \text { الملخص العربى }
\end{aligned}
$$

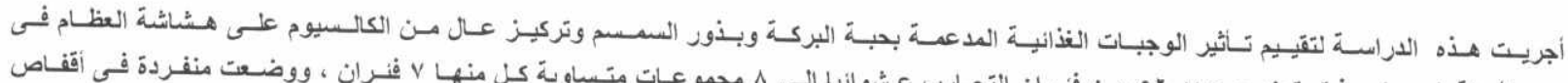

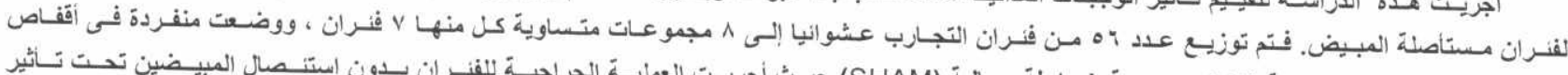

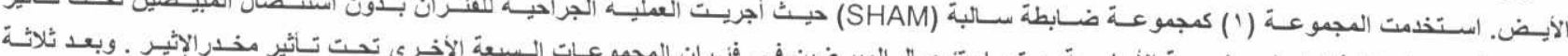

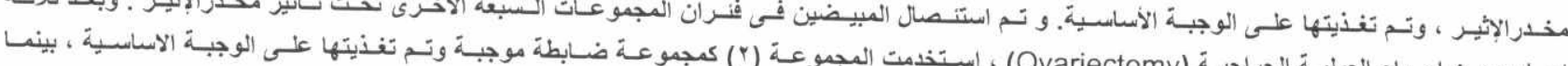

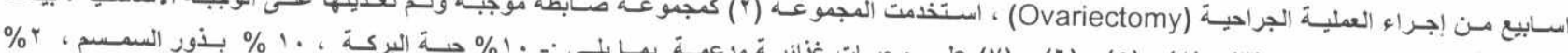

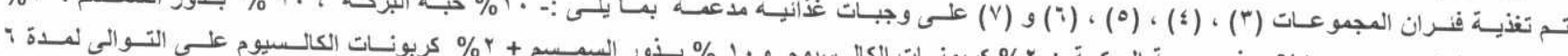

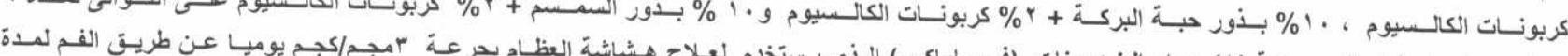

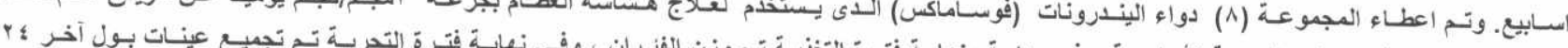

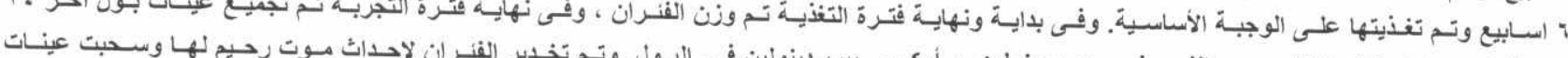

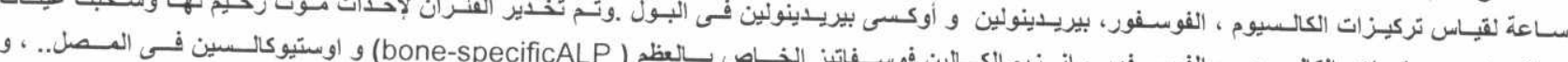

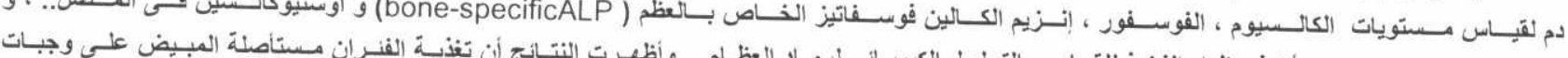

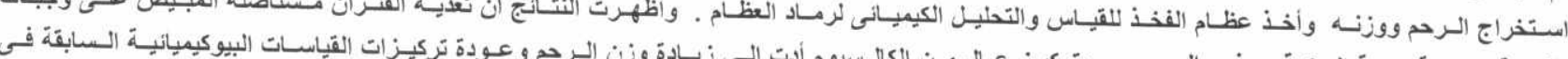

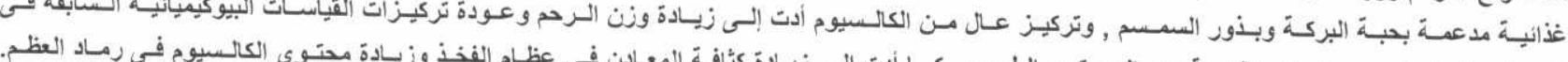

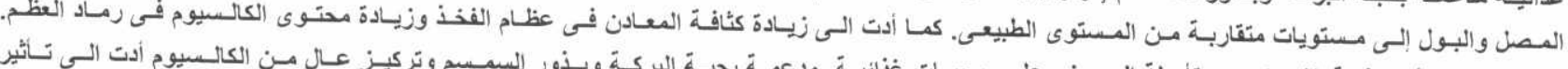

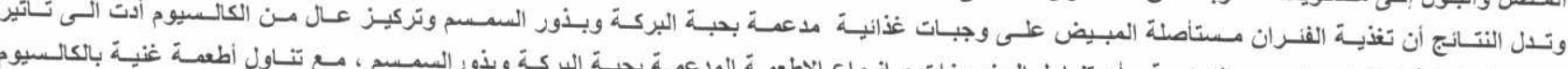

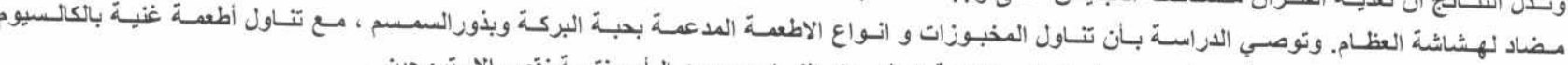

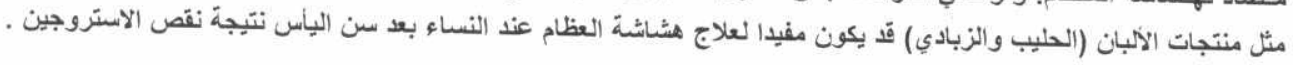

